\title{
THE IMPACT OF MUSIC ON INTERIOR DESIGN EDUCATION
}

\author{
Nada Ahmed ARISHA *
}

Faculty of Arts \& Design, October University for Modern Sciences and Arts, Egypt

\begin{abstract}
Music is a source of creative inspiration in various art fields. It raises the conscience of the viewer and the listener with all the meanings of beauty. Music has a great role in learning design, as it elevates the soul and the psychological side of the interior designer. Interior design is one of the fields of applied arts, which is concerned with the designs of various architectural buildings such as theatres, exhibitions and museums, which have a great role in the society, also its studying related to the design considerations of the users of buildings. Music has a large and influential role in learning design aspects of interior design. There has been a global trend nowadays to integrate the interdisciplinary studies, unify the arts and guide the learner and practitioner of interior design to study Music. Consequently experiments appeared for various international designs resulting from converting the sound-frequency of music to architecture and interior design.

Keywords

IMPACT, MUSIC, INTERIOR DESIGN, EDUCATION
\end{abstract}

\section{Introduction:}

The approach of this research is to explore the relationship between learning music and learning interior design in a creative and innovative way that combines both disciplines as a trend in art learning, which includes the interior design in a contemporary, creative and artistic context. Keywords: Music - Interior Design - Visual Arts - Learning - Creativity - Formal Formation Interdisciplinary Studies - Talent - Hearing - Theater - Design Considerations - Contemporary.

\section{1- About the art of music:}

Music comes at the fore among all the arts, as it is the most influential of man and penetrates his depths, equal in this for all people as it is the language of human beings in general, which is not available for another art. I will not attain this language, which is unique in that characteristic, and what strengthens it, so that it stimulates us from feelings.

Music is the only language of the world that all people are aware of, regardless of their different backgrounds, races, beliefs, principles and ideas. Hence, music is the ideal means that transmits the artist's emotional experiences to the listener's sense.

Music was a year "one of the factors of pioneering, advancement and creativity of the ancient Egyptian society. Music created a suitable environment for creativity. As much as the Egyptian society excelled in architecture, interior design and all the arts; I loved music and singing, so he listened to music as he innovated by constructing huge buildings and recording the most wonderful for us." Arts. The results of his work were distinguished, indicating creativity and originality, and combining the art of music, architecture and interior design.

* Corresponding author: info@msa.eun.eg 


\section{2- Music as "a source of inspiration for architecture and interior design":}

There is a close relationship between music, architecture and interior design. Music has been a source of creative inspiration for designers. This is evidenced by what critic Max Locke said, "Goethe's point of view," he said, "Architecture is a Frozen Music.” Where he compared and related between the facades of buildings and the musical notes and considered that the rhythm is the broad base linking architecture, interior design and music, and that the strength of these two arts depends on the regularity. For example: the distance between the columns forms the rhythm that shapes the time of music, and the diversity in The colors, light and shade are matched by the variety of tones, and the contrast in the texture of the surfaces can be noticed in the musical difference in the intensity of the sounds up and down.

A modern architectural trend has emerged, which means the need to pay attention to "interdisciplinary studies", which include studying two branches of the arts or different sciences and trying to establish points of convergence between them. Music takes center stage in the auditory arts which can be transformed into a visual sensory image. And with music, the architectural and interior design works can be re-read, perceived and learned from the perspective of the Environmental Studies Unit, and to form a source of creative inspiration for the learner and the reader of the artwork.

The critic Charles Jencks, in his article Architecture Becomes Music, said that there is a relationship between architecture and music, and that the architectural works can be re-read from the perspective of musicology, and he analyzed the facade of the Caixa Forum in Madrid, Spain. It is a museum and cultural center which was designed by the architect Herz00g \& De Meuron in 2003-2008, and he analyzed it on the horizontal level and it consists of 3, 4 or 5 opposing sounds based on the reader of the architectural work) represented by the iron ore above the mini, Brick, and at the bottom of the building are black. The sum of what is staged according to the rhythms of contrasting raw materials is likened to the strength of the strings of the composer Stravinsky (18821971) in his symphony, The Rite of "spring, which he composed in 1913. (2)

\section{3- Musical construction rules:}

Musical construction rules include both the solfih, and the hearing exercises, which include hearing levels. Music has a great impact on the interior designer's learning in terms of raising his sensory and auditory side.

\section{1 - 3 Solfege:}

The term "solfege" is defined in the music lexicon as a music educational system for training in listening, singing, and reading musical notes.After solfege, one of the first most important 
basics in the study of music is playing or singing, training, education and hearing the notes in a correct manner, and familiarity with the symbols and signs used in writing music and grammar Governing it in terms of setting tones, and temporal values in terms of length and shortness.

\section{2 - 3 levels of hearing for music:}

Music is considered one of the auditory arts, which directly affects the recipient of the interior design learner through hearing. It makes him aware of her aesthetics and her emotions, and stimulates within him self-imaginations that are reflected through his hearing of music. Music has abstract expressions through melodies, rhythms and performance.

And listen to music according to the following levels:

1- The Sensory Level:

It is considered the simplest method of listening to music, in which the listener is in a state of pure listening without thinking, and it is the phase of feeling that arises by enjoying the sound of music and surrendering to the world of imagination.

2- Expressive level:

It is the second level of listening, as it works to clarify the meaning of music and singing through what the composer wanted from his expression, and it is considered one of the most difficult levels to understand due to the difficulty of defining a special meaning for music because it is an art of hearing. Music readers or high competence and not the ordinary listener, as it is necessary for the listener to be aware of the principles of music construction and formalism, as it requires the process of understanding in the process of excellence and experience to know it.

\section{Results:}

At the end of the research, the researcher reached several results, which we mention as follows: 1- A report on the relationship between music and interior design, beginning with the ancient Egyptian civilization, which expressed the interconnectedness of arts with each other and their image on the walls.

2- That music is a source of creative inspiration for the student, the learner, and the practitioner of interior design.

3- That there is a link between the stages of the formation of the artwork between music and the interior designer, which includes:

- (Pre-production music is the stage of crystallization of the design idea).

- $($ The stage of musical notation $=$ drawing design work).

- (Embodying the musical work and reviewing the work for a taste of it = embodying the 
design work in a three-dimensional way and outputting it into existence).

4- There is a contemporary architectural trend that means linking music, architecture and interior design; Whether by converting musical notes into a form, or by formal inspiration for musicians such as the musician:

- Johann Sebastien Bach (1685-1750)

- Ludwig Van Beethoven (1770-1827).

\section{References:}

1- Okasha's wealth. Time and the Weaving of Melody (From Apollo's Canticle to Turangalila), Part Fourteen, Second Edition, Egyptian General Book Authority, Cairo, Egypt, 1996.

2- Khairy Ibrahim Al-Malt, Music and Society in Ancient Egypt, The Egyptian General Book Authority, 2017 (Introduction to the book by Professor Abdel Halim Nour El-Din (Dean of the Faculty of Archeology - Cairo University - Fayoum Branch previously).

3- Thorpe Davy, translated and commented by: Dr. Samha El-Khouly, Musical Analysis, Second Edition, The National Project for Translation, Supreme Council of Culture, Egypt, 2000 .

4- Aziz Al-Shwan. Music (tonal expression - logic), The Alf Book (the second), Egyptian General Book Authority, Cairo, Egypt, 1986.

5- Ali Abdel-Raouf, Architectural Criticism and its Role in the Development of Contemporary Urbanism (The Egyptian and Arab Case), 2014.

6- Academy of the Arabic Language. Music Dictionary, Second Edition, General Authority for Emiri Press Affairs, Cairo, Egypt, 2008.

7- Mayssam Hormuz Touma, The Elements of Formation of Music and Singing (A Research Perspective), Al-Fath, Baghdad, 2018.

8- Dodsworth. Simon, The Fundamentals of Interior Design, Ava Academia "The environment learning", Switzerland, 2009, P. 8-17.

9- Nevin Mohamed Kamal El Din FATHY, THE EFFECTIVENESS OF A PROPOSED PROGRAM BASED ON BLENDED LEARNING TO DEVELOP ACHIEVEMENT IN WESTERN MUSIC GRAMMAR FOR STUDENTS OF THE FACULTY OF SPECIFIC EDUCATION, International Journal of Education and Learning Research, Vol. 2, No. 2, 2019, pp. 16-21.

10- Jacqueline Jamal SIDHOM, Mahmoud Ahmed AL-WAKEEL, THE EFFECTIVENESS OF SCAMPER'S STRATEGY FOR DEVELOPING CREATIVE THINKING IN THE SUBJECT OF HARMONY FOR MUSIC EDUCATION STUDENTS, International Journal of Education and Learning Research, Vol. 2, No. 2, 2019, pp. 22-40. 
11-https://www.architectural-review.com/essays/viewpoints/architecture-becomes music/8647050.article

12-http://www.experience-ancient-egypt.com/ancient-egyptian-culture/ancientegyptianart/ancient-egyptian-music

13-https://www.louvre.fr/en/oeuvre-notices/harpist-s-stele

14-https://www.archdaily.com/162195/busan-opera-house-proposal-orproject

15-http://www.zaha-hadid.com/architecture/js-bach-chamber-music-hall

16-http://www.archtalent.com/projects/beethoven-concert-hall

Received: February 25, 2020

Accepted: April 10, 2020 